\title{
Sistem Pendukung Keputusan Diagnosa Penyakit Tanaman Cabai Merah Menggunakan Metode TOPSIS Berbasis Web di Desa Kerik Magetan Jawa Timur
}

\author{
Pebri Romadhon ${ }^{1}$, Tomi Tristono ${ }^{2}$, Pradityo Utomo ${ }^{3}$ \\ 1,2,3 Informatics Management, Merdeka Madiun University, Madiun, Idnonesia \\ Email: 1ffebri080296@gmail.com, ${ }^{2}$ tomitristono@gmail.com, ${ }^{3}$ pradityou@gmail.com
}

\begin{abstract}
Kerik Village, Takeran District, Magetan Regency, part of the community, work as red chilli farmers. Farmers experience some difficulties in red chilli cultivation because farmers still have little experience in red chilli cultivation. The farmers cannot know the types of diseases and pests and the symptoms that hit chilli plants that can reduce the productivity of chilli plants and can even cause crop failure. In addition, farmers also do not have experience handling it when they encounter problems that hit chilli plants that are being cultivated. To assist farmers in overcoming these problems, a web-based decision support system was built using the Technique for Order of Preference by Similarity to Ideal Solution (TOPSIS) method. The decision support system was created and designed using the Waterfall method and tested using the Blackbox Testing system testing method. With this decision support system, it is hoped that it will help farmers in Kerik Village diagnose diseases of the red chilli plants they cultivate. The test results from the Decision Support System for Diagnosing Red Chili Plant Diseases Using the Web-Based TOPSIS Method got the results as expected with the Blackbox Testing test, which brought the results of the percentage of system success of $100 \%$.
\end{abstract}

Keywords: Decision Support System, TOPSIS, Chili Plant Disease Diagnosis, Blackbox Testing, Waterfall

\section{PENDAHULUAN}

Salah satu wilayah di daerah Jawa Timur, tepatnya di desa Kerik Kecamatan Takeran Kabupaten Magetan, sebagian besar masyarakatnya berprofesi sebagai petani. Pada jaman dahulu kebanyakan para petani di desa Kerik berfokus pada tanaman padi, namun akhir-akhir ini banyak yang bermigrasi ke tanaman cabai merah. Para petani lebih berani mengambil resiko untuk menanam cabai merah karena tanaman cabai merah dirasa lebih mempunyai tingkat ekonomis yang lebih tinggi dari pada tanaman padi. Langkah yang 


\section{Journal of Software Engineering Ampera}

Vol. 2, No. 1, February 2021 e-ISSN: 2775-2488

https://journal-computing.org/index.php/journal-sea/index

diambil oleh para petani untuk menanam cabai merah bukan suatu hal yang mudah, karena merupakan kasus baru dalam pekerjaan yang mereka laksanakan. Tentunya, para petani akan menemui beberapa masalah karena merupakan suatu hal yang baru dan kurangnya pengalaman dalam budidaya tanaman cabai merah. Para petani kurang mampu untuk mengetahui jenis penyakit dan hama maupun gejala-gejala yang melanda tanaman cabai yang dapat menurunkan produktivitas tanaman cabai, bahkan dapat menyebabkan gagal panen. Para petani juga belum mempunyai pengalaman bagaimanakah cara penanganan yang harus dilakukan saat menemui masalah yang melanda tanaman cabai yang sedang di budidaya. Berdasarkan pada masalah-masalah yang di sebutkan diatas, pada penelitian ini membahas masalah sistem pendukung keputusan dengan menggunakan metode Technique for Order of Preference by Similarity to Ideal Solution (TOPSIS) yang akan bekerja untuk menentukan jenis penyakit berdasarkan gejala dan hama pada tanaman cabai merah khususnya gejala yang terjadi pada daun tanaman cabai merah. Penulis akan membahas tentang sistem pendukung keputusan diagnosa penyakit tanaman cabai merah menggunakan metode TOPSIS berbasis Web.

Beberapa penelitian terkait yang digunakan untuk mendukung penelitian ini antara lain : pada penelitian sebelumnya telah dilakukan penelitian tentang sistem pendukung keputusan dalam diagnosa penyakit anemia dengan menggunakan metode Simple Additive Weighting (SAW) oleh Anggareni dkk pada tahun 2016. Dalam sistem pendukung keputusan ini dapat digunakan untuk mengetahui jenis-jenis penyakit, gejala dan penangannya agar resiko yang mungkin ditimbulkan dapat diminimalisasi. SPK ini dapat dibuat agar dapat digunakan oleh dokter maupun masyarakat dimana saja dan kapan saja dengan mudah [1]. Pada penelitian yang dibuat oleh Haryo dan Rudy pada Tahun 2016 dengan judul penelitian Sistem Pendukung Keputusan penentuan tanaman obat sesuai jenis penyakit menggunakan metode TOPSIS. Dengan penelitian ini diharapkan dapat membantu masyarakat dalam menentukan tanaman obat yang direkomendasikan benar benar sesuai dengan keinginan, kebutuhan, dan kemampuan konsumen [2].

Selanjutnya pada tahun 2012 dilakukan penelitian mengenai diagnosa hama dan penyakit pada tanaman juga dilakukan oleh Feriadi. Penelitian tersebut berjudul Sistem Pendukung Keputusan untuk Simulasi Diagnosa Hama dan Penyakit pada Tanaman Cabai. Metode yang digunakan dalam sistem 


\section{Journal of Software Engineering Ampera}

Vol. 2, No. 1, February 2021 e-ISSN: 2775-2488

https://journal-computing.org/index.php/journal-sea/index

pendukung keputusan ini dikembangkan menggunakan metode waterfall. Sistem pendukung keputusan ini dibuat aplikasi yang dapat menentukan penyakit serta solusi untuk mengatasi hama atau penyakit yang menyerang tanaman cabai tersebut [3]. Kemudian pada tahun 2019 dilakukan penelitian mengenai sistem pakar menggunakan metode Forward Chaining dengan basis android oleh Irnaldi. Sistem pakar yang dibuat ditujukan untuk para petani dalam mendiagnosa penyakit tanaman cabai dan cara penanganannya secara cepat dan efektif, dengan begitu para petani tidak perlu menunggu tenaga ahli dalam bidang pertanian [4].

Setiawan dkk juga melakukan penelitian tentang diagnosa penyakit dan hama pada tanaman salak di Turi Sleman pada tahun 2017. Sistem pendukung keputusan ini menggunakan sistem pakar yaitu metode TOPSIS yang menghasilkan kesimpulan nilai akhir dengan rank tertinggi. SPK ini membantu petugas dalam mengenali hama dan penyakit yang dapat menyerang tanaman salak sehingga dapat mengurangi kegagalan [5]. Penelitian mengenai sistem pakar diagnosa penyakit tanaman kelapa sawit dengan metode bayes dengan study kasus PT. Ukindo Blangkahan Estate yang dilakukan oleh Akim dan Novriyenni. Penelitian tersebut berjudul Sistem pakar diagnosa penyakit tanaman kelapa sawit dengan metode bayes dengan study kasus PT. Ukindo Blangkahan Estate. Metode yang digunakan dalam sistem pakar ini dikembangkan menggunakan metode waterfall. Sistem pakar ini dibuat aplikasi yang dapat menentukan penyakit serta solusi untuk mengatasi hama atau penyakit yang menyerang tanaman kelapa sawit tersebut [6].

Pada Tahun 2020 dilakukan penelitian tentang Sistem Pendukung Keputusan Metode TOPSIS untuk diagnosa penyakit demam berdarah oleh Priyono dan Nuzuliarini. Dengan penelitian ini diharapkan dapat membantu masyarakat dalam menentukan diagnose penyakit Demam berdarah dengan beberapa gejala yang mirip dengan penyakit lainnya dengan menentuan uji realibitas dan dibuat perangkingan suatu nilai sebagai acuan dalam mengambil keputusan diagnosa suatu penyakit, sehingga pasien yang datang pada rumah sakit langsung dapat diatasi dengan melihat dari gejala-gejala penyakitnya [7]. Pada tahun 2018 juga telah dilakukan penelitian mengenai sistem pendukung keputusan menggunakan metode Naive Bayes Classifier oleh Puspito dkk dengan judul Sistem Pendukung Keputusan Diagnosa Penyakit Tanaman Jeruk Menggunakan Metode Naive Bayes Classifier. Sistem pendukung keputusan ini 


\section{Journal of Software Engineering Ampera}

Vol. 2, No. 1, February 2021 e-ISSN: 2775-2488

https://journal-computing.org/index.php/journal-sea/index

dibuat untuk membantu petani dalam mengklasifikasikan jenis-jenis gejala penyakit tanaman jeruk agar petani tidak mengalami kerugian akibat serangan virus dan hama lainnya. Variabel yang digunakan dalam penelitian ini adalah daun, buah, batang dan akar tanaman jeruk [8].

Pada Tahun 2018 dilakukan penelitian tentang Sistem Pendukung Keputusan Menentukan Penyakit pada Tanaman Kakao Menggunakan Metode TOPSIS oleh Suyono dan Carnovia. Petani banyak yang mengeluhkan hasil panen kakaonya berkurang karena tanamannya terserang penyakit. Oleh karena itu, sistem pendukung keputusan ini digunakan untuk membantu petani dalam mengetahui penyakit-penyakit yang dapat menyerang tanaman kakaonya dengan menggunakan kriteria-kriteria yang ditemukan dilapangan [9]. Novi dkk juga melakukan penelitian tentang diagnosa penyakit pada tanaman kacang kedelai pada tahun 2018. Sistem pendukung keputusan ini menggunakan sistem pakar yaitu metode certainty factor yang menghasilkan kesimpulan nilai akhir dengan rank tertinggi. SPK ini membantu masyarakat dalam mengenali hama dan penyakit yang menyerang tanaman kacang kedelai sehingga dapat mengurangi kegagalan panen [10].

\section{METODOLOGI PENELITIAN}

\subsection{Technique for Order of Preference by Similarity to Ideal Solution (TOPSIS)}

TOPSIS merupakan sebuah metode pengambilan keputusan multikriteria, dengan prinsip alternatif yang mempunyai jarak terdekat dengan solusi ideal positif dan alternatif yang mempunyai jarak terjauh dengan solusi ideal negatif. Dengan pengecualian bahwa alternatif yang mempunyai jarak terdekat dengan solusi ideal positif tidak harus mempunyai jarak solusi ideal negatif dengan alternatif yang mempunyai jarak terjauh. Metode TOPSIS menentukan sebuah solusi yang optimal dengan metode menetukan kedekatan realtif sebuah alternatif terhadap solusi ideal positif. Alternatif-alternatif yang dijadikan perangkingan didapatkan dari prioritas nilai kedekatan relatif sebuah alternatif terhadap solusi ideal positif [5]. Langkah-langkah yang dilakukan untuk penyelesaian masalah dengan metode TOPSIS adalah sebagai berikut [4]:

1) Menentukan Matriks Keputusan Ternormalisasi (R). 


\section{Journal of Software Engineering Ampera}

Vol. 2, No. 1, February 2021 e-ISSN: 2775-2488

https://journal-computing.org/index.php/journal-sea/index

$$
r_{i j}=\frac{x^{i j}}{\sqrt{\sum_{i=1}^{m} X^{2} i^{j}}}
$$

2) Menentukan Matriks Keputusan yang Ternormalisasi Terbobot (Y).

$$
\boldsymbol{y}_{i j}=\boldsymbol{w}_{j} \cdot \boldsymbol{r}_{i j}
$$

3) Menentukan Matriks Solusi Ideal Positif $\left(A^{+}\right)$dan Solusi Ideal Negatif $\left(A^{-}\right)$ Solusi Ideal Positif $\left(\mathrm{A}^{+}\right)$

$$
\begin{array}{r}
A^{+}=\left\{\left(\max _{i j} \mid j \in J\right),\left(\operatorname{miny}_{i j} \mid j \in J^{\prime}\right), i=1,2,3, \ldots, m\right\} \\
A^{+}=\left(y_{1}^{+}, \boldsymbol{y}_{2}^{+}, \boldsymbol{y}_{3}^{+}, \ldots, \boldsymbol{y}_{\boldsymbol{n}}^{+}\right) \ldots \ldots \ldots \ldots \ldots \ldots \ldots \ldots \ldots \ldots \ldots \ldots \ldots
\end{array}
$$

Dengan ketentuan :

$$
y_{-}^{+}=\left\{\begin{array}{c}
\max y_{i j}=j i k a j \text { adalah atribut keuntungan (benefit) } \\
\min y_{i j}=j i k a j \text { adalah atribut biaya }(\text { cost })
\end{array}\right.
$$

Solusi Ideal Negatif ( $\left.A^{-}\right)$

$$
\begin{array}{r}
A^{-}=\left\{\left(\min _{i j} \mid j \in J\right),\left(\max _{i j} \mid j \in J^{\prime}\right), i=1,2,3, \ldots, m\right\} \\
A^{-}=\left(y_{1}^{-}, y_{2}^{-}, y_{3}^{-}, \ldots, y_{n}^{-}\right) \ldots \ldots \ldots \ldots \ldots \ldots \ldots \ldots \ldots \ldots \ldots \ldots \ldots \ldots
\end{array}
$$

Dengan ketentuan :

$$
\begin{aligned}
& y_{-}^{-} \\
& =\left\{\begin{array}{c}
\max y_{i j}=j \text { ika } j \text { adalah atribut biaya }(\text { cost }) \\
\min y_{i j}=j i k a j \text { adalah atribut keuntungan (benefit) }
\end{array}\right.
\end{aligned}
$$

4) Menentukan Jarak Solusi Ideal Positif dan Negatif (D).

Jarak antara Alternatif $A_{i}$ dengan Solusi Ideal Positif $\left(D^{+}\right)$

$$
D_{i}^{+}=\sqrt{\sum_{j=1}^{n}\left(y_{i}^{+}-y_{i j}\right)^{2}}
$$

Jarak antara Alternatif $A_{i}$ dengan Solusi Ideal Negatif ( $D^{-}$)

$$
D_{i}^{-}=\sqrt{\sum_{j=1}^{n}\left(y_{i j}-y_{j}^{-}\right)^{2}}
$$

5) Mencari Nilai Preferensi (V).

Nilai preferensi untuk setiap alternatif $\left(V_{i}\right)$ diberikan sebagai berikut :

$$
\boldsymbol{V}_{\boldsymbol{i}}=\frac{\boldsymbol{D}_{\boldsymbol{i}}^{-}}{\boldsymbol{D}_{\boldsymbol{i}}^{-}+\boldsymbol{D}_{\boldsymbol{i}}^{+}}
$$

Nilai $V_{i}$ terbesar menunjukkan bahwa alternatif $A_{i}$ yang dipilih. 


\section{Journal of Software Engineering Ampera}

Vol. 2, No. 1, February 2021 e-ISSN: 2775-2488

https://journal-computing.org/index.php/journal-sea/index

\section{HASIL DAN PEMBAHASAN}

\subsection{Usecase Diagram}

Desain use case diagram sistem pendukung keputusan diagnosa penyakit tanaman cabai merah menggunakan metode TOPSIS berbasis web di desa Kerik dapat dilihat pada Gambar 1.

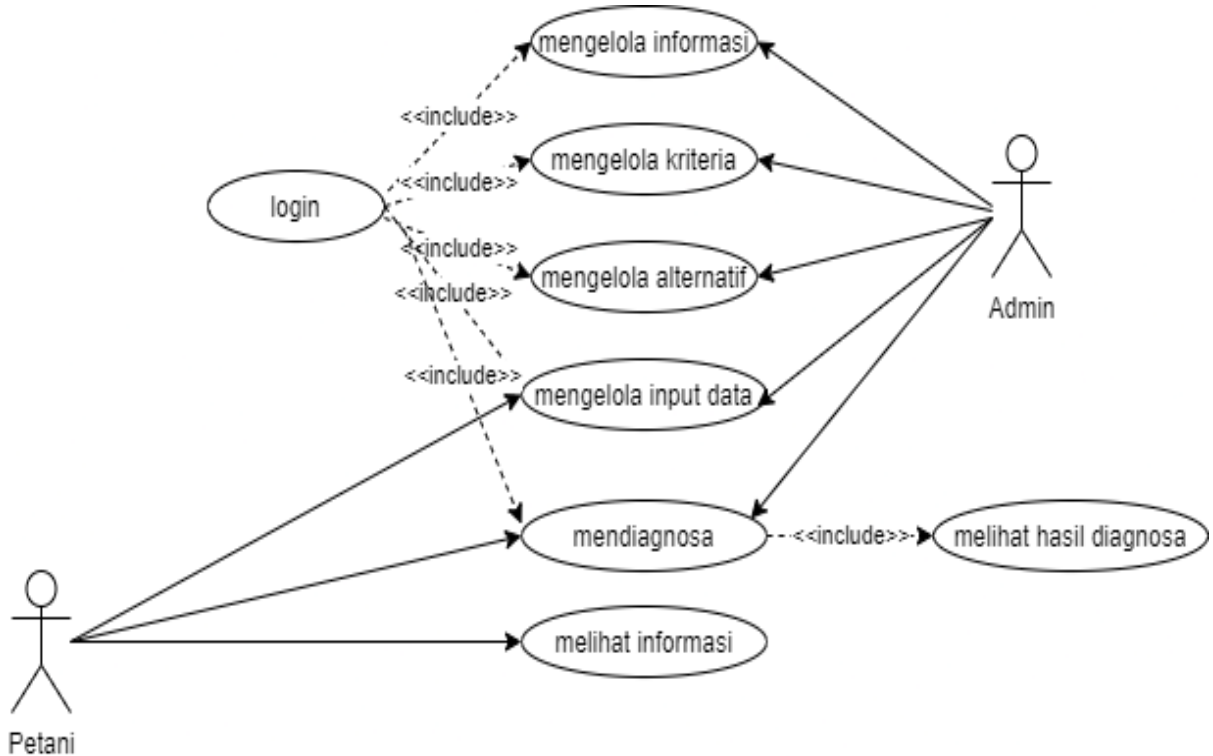

Gambar 1. Use Case Diagram

\subsection{Entity Relationship Diagram}

ERD Sistem Pendukung Keputusan Diagnosa Penyakit Tanaman Cabai Merah ini menjelaskan bahwa pada setiap tabel saling memiliki keterkaitan satu dengan lainnya. Database dari sistem pendukung keputusan ini menjelaskan adanya relasi dari setiap tabel yang dirancang. Database dari sistem ini mempunyai 5 (Lima) tabel, tabel-tabel dari database yang telah dirancang adalah antara lain : tabel topsis_admin, tabel topsis_alternatif, tabel topsis_kriteria, tabel topsis_perhitungan dan tabel topsis_informasi. Untuk lebih jelas dapat dilihat pada Gambar 2. 
Journal of Software Engineering Ampera

Vol. 2, No. 1, February 2021 e-ISSN: 2775-2488

https://journal-computing.org/index.php/journal-sea/index

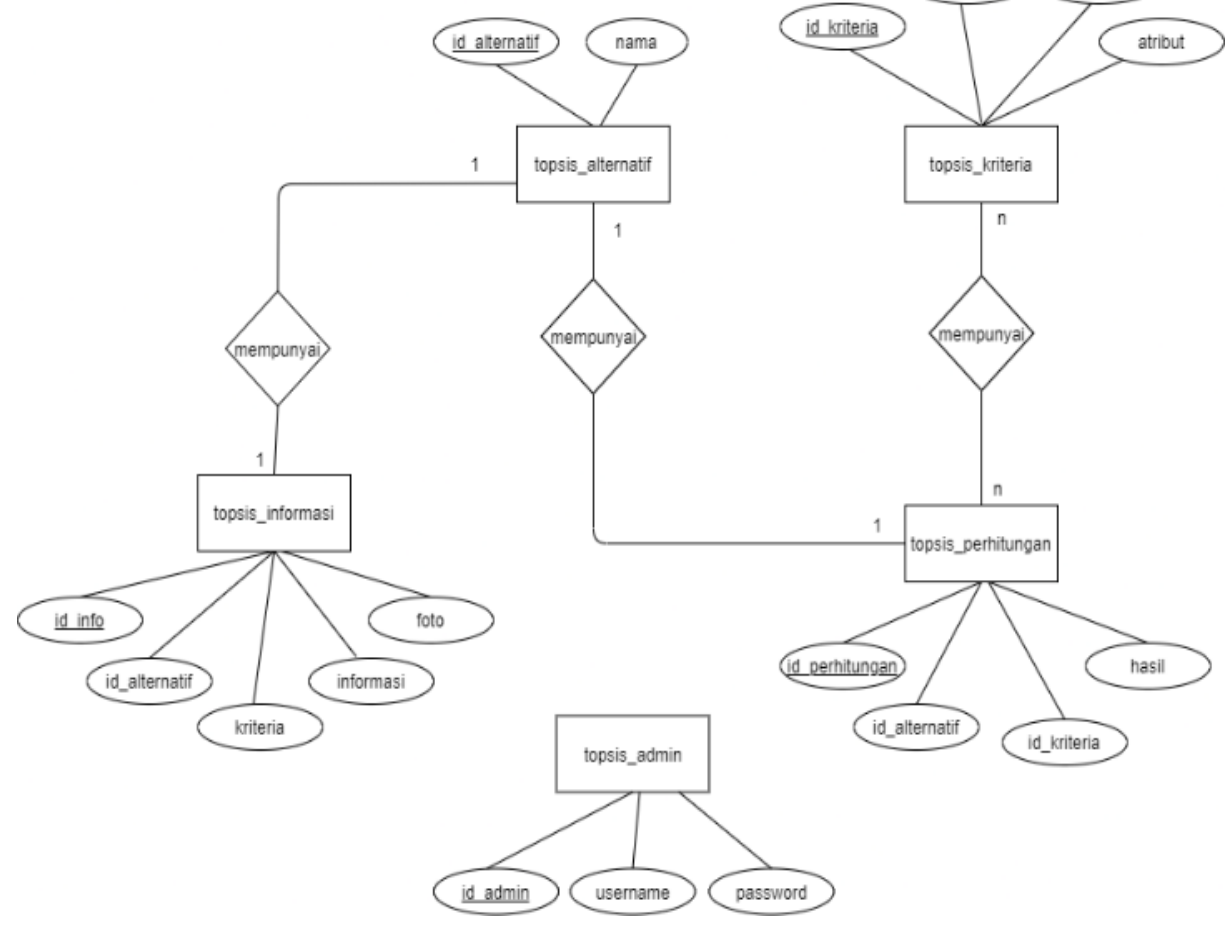

Gambar 2. Entity Relationship Diagram

\subsection{Perhitungan Metode TOPSIS}

\subsubsection{Kriteria dan Pembobotan}

Tabel 1. Kriteria dan Pembobotan

\begin{tabular}{ccccc}
\hline No. & Kriteria & Kategori & Nilai Bobot & Bobot \\
\hline 1. & $\begin{array}{c}\text { Daun mengalami } \\
\text { kelayuan }\end{array}$ & Cost & Sangat Tinggi & 5 \\
2. & $\begin{array}{c}\text { Daun menguning dan } \\
\text { menjalar ke ranting } \\
\text { Warna jaringan akar dan } \\
\text { batang menjadi coklat }\end{array}$ & Cost & Tinggi & 4 \\
Layu secara tiba-tiba & Cost & Tinggi & 4 \\
4. & $\begin{array}{c}\text { Lest } \\
\text { 5. }\end{array}$ & Tinggi & 4 \\
& Cost & Sangat Tinggi & 5
\end{tabular}




\section{Journal of Software Engineering Ampera}

Vol. 2, No. 1, February 2021 e-ISSN: 2775-2488

https://journal-computing.org/index.php/journal-sea/index

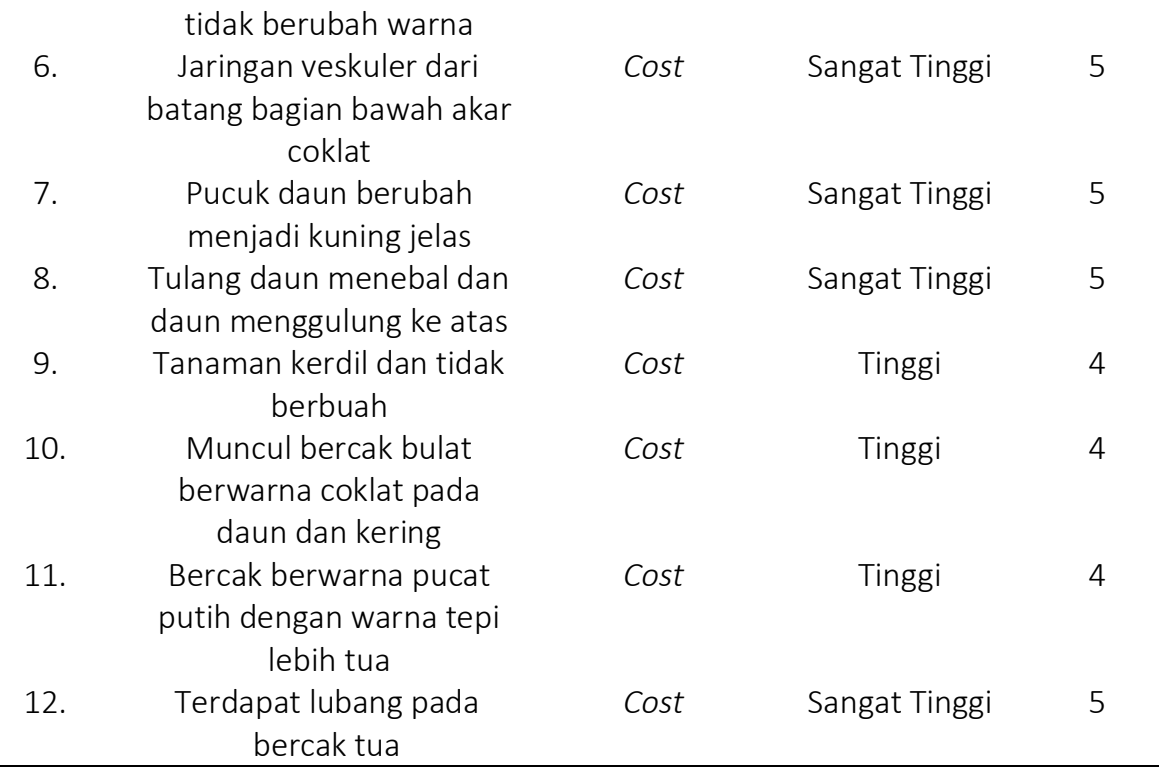

Pada analisa pembobotan metode TOPSIS ini di butuhkan bobot dan kriteria yang dijadikan menjadi parameter untuk melaksanakan perhitungan untuk dapat menghasilkan alternatif terbaik dengan nilai (V) terbesar dari perhitungan tersebut, maka disusunlah lima tingkat kepentingan dalam metode TOPSIS. Lima tingkat kepentingan yang sudah ditentukan dapat dilihat pada Tabel 2.

Tabel 2. Tingkat Kepentingan

\begin{tabular}{ccc}
\hline No. & Tingkat Kepentingan & Bobot \\
\hline 1. & Sangat Tinggi (ST) & 5 \\
2. & Tinggi (T) & 4 \\
3. & Cukup (C) & 3 \\
4. & Rendah (R) & 2 \\
5. & Sangat Rendah (SR) & 1 \\
\hline
\end{tabular}

\subsubsection{Menentukan Rating Kecocokan}

Setelah melakukan penilaian terhadap setiap alternatif maka didapatkan rating kecocokan. Tabel Rating Kecocokan dapat dilihat pada Tabel 3 berikut. 


\section{Journal of Software Engineering Ampera}

Vol. 2, No. 1, February 2021 e-ISSN: 2775-2488

https://journal-computing.org/index.php/journal-sea/index

Tabel 3. Rating Kecocokan

\begin{tabular}{lllllllllllll}
\hline Alternatif & \multicolumn{10}{c}{ Kriteria } \\
\cline { 2 - 12 } & C1 & C2 & C3 & C4 & C5 & C6 & C7 & C8 & C9 & C10 & C11 & C12 \\
\hline A1 & 5 & 5 & 4 & 4 & 4 & 3 & 3 & 4 & 4 & 3 & 3 & 4 \\
A2 & 1 & 4 & 4 & 5 & 5 & 4 & 3 & 3 & 2 & 3 & 3 & 2 \\
A3 & 4 & 4 & 4 & 3 & 3 & 4 & 4 & 4 & 4 & 4 & 3 & 3 \\
A4 & 3 & 3 & 4 & 4 & 3 & 3 & 4 & 2 & 3 & 4 & 4 & 4 \\
\hline
\end{tabular}

Implementasi halaman Evalution Matrix (Xij) dapat dilihat pada Gambar 3 berikut :

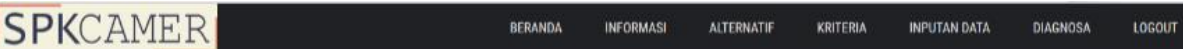

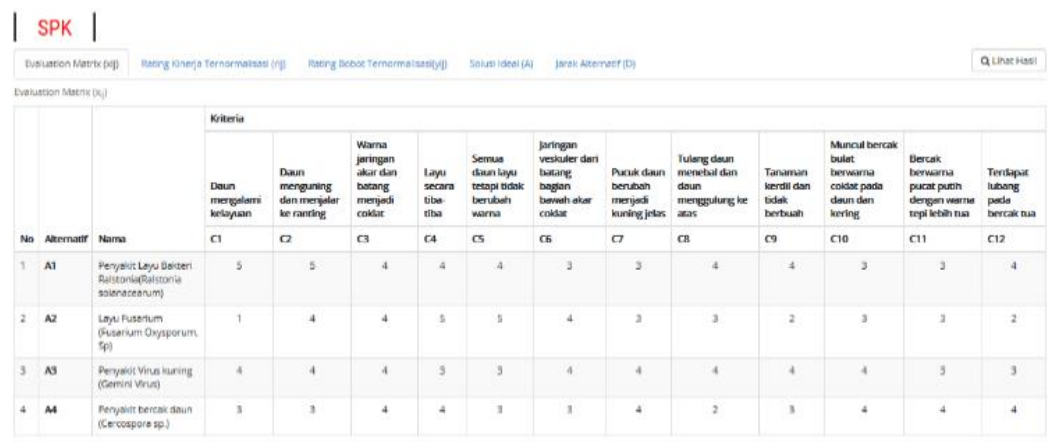

Gambar 3. Halaman Evaluation Matrix (xij)

\subsubsection{Menentukan Rating Kinerja Ternormalisasi}

Perhitungan nilai rating kinerja ternormalisasi. Untuk membuat matriks ternormalisasi setiap nilai kriteria dibagi dengan bobot pembaginya. Persamaan yang digunakan untuk mentransformasikan setiap elemen xij dengan rumus 1, maka didapatkan hasil perhitungan rating kinerja ternormalisasi yang dapat dilihat pada Tabel 4 berikut.

Tabel 4. Rating Kinerja Ternormalisasi

\begin{tabular}{|c|c|c|c|c|c|c|c|c|c|c|c|c|}
\hline \multirow{3}{*}{$\begin{array}{l}\text { Alter } \\
\text { natif }\end{array}$} & \multicolumn{12}{|c|}{ Kriteria } \\
\hline & C1 & $\mathrm{C} 2$ & $\mathrm{C} 3$ & $\mathrm{C} 4$ & $\mathrm{C} 5$ & C6 & C7 & C8 & $\mathrm{C9}$ & $\mathrm{C} 1$ & $\mathrm{C} 1$ & C1 \\
\hline & & & & & & & & & & 0 & 1 & 2 \\
\hline
\end{tabular}




\section{Journal of Software Engineering Ampera}

Vol. 2, No. 1, February 2021 e-ISSN: 2775-2488

https://journal-computing.org/index.php/journal-sea/index

\begin{tabular}{lllllllllllll}
\hline A1 & 0,7 & 0,6 & 0,5 & 0,4 & 0,5 & 0,4 & 0,4 & 0,5 & 0,5 & 0,4 & 0,4 & 0,5 \\
& 00 & 15 & 00 & 92 & 20 & 24 & 24 & 96 & 96 & 24 & 57 & 96 \\
& 1 & 5 & 0 & 4 & 8 & 3 & 3 & 3 & 3 & 3 & 5 & 3 \\
A2 & 0,1 & 0,4 & 0,5 & 0,6 & 0,6 & 0,5 & 0,4 & 0,4 & 0,2 & 0,4 & 0,4 & 0,2 \\
& 40 & 92 & 00 & 15 & 50 & 65 & 24 & 47 & 98 & 24 & 57 & 98 \\
& 0 & 4 & 0 & 5 & 9 & 7 & 3 & 2 & 1 & 3 & 5 & 1 \\
A3 & 0,5 & 0,4 & 0,5 & 0,3 & 0,3 & 0,5 & 0,5 & 0,5 & 0,5 & 0,5 & 0,4 & 0,4 \\
& 60 & 92 & 00 & 69 & 90 & 65 & 65 & 96 & 96 & 65 & 57 & 47 \\
& 1 & 4 & 0 & 3 & 6 & 7 & 7 & 3 & 3 & 7 & 5 & 2 \\
A4 & 0,4 & 0,3 & 0,5 & 0,4 & 0,3 & 0,4 & 0,5 & 0,2 & 0,4 & 0,5 & 0,6 & 0,5 \\
& 20 & 69 & 00 & 92 & 90 & 24 & 65 & 98 & 47 & 65 & 10 & 96 \\
& 1 & 3 & 0 & 4 & 6 & 3 & 7 & 1 & 2 & 7 & 0 & 3 \\
\hline
\end{tabular}

Implementasi halaman Rating Kinerja Ternormalisasi (Rij) dapat dilihat pada Gambar 4 berikut :

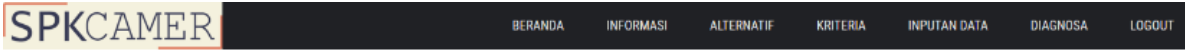

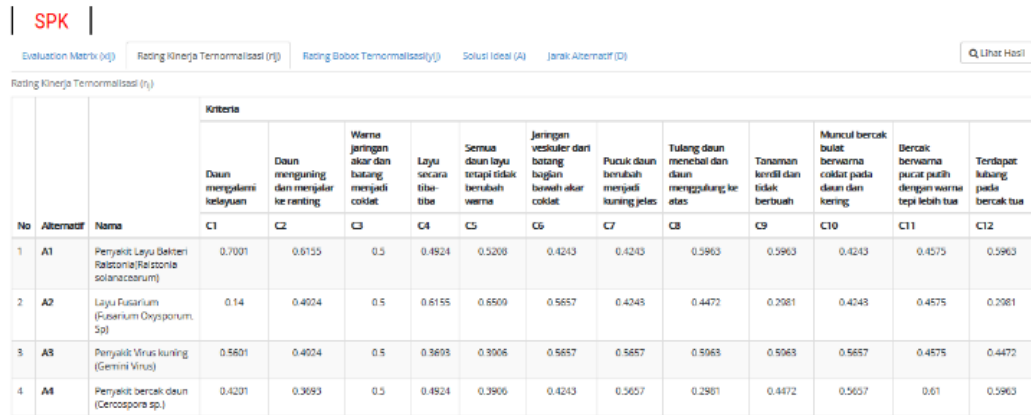

Gambar 4. Halaman Rating Kinerja Ternormalisasi (rij)

\subsubsection{Menentukan Rating Bobot Ternormalisasi}

Perhitungan nilai rating bobot ternormalisasi, nilai tersebut didapatkan dengan langkah untuk mengalikan setiap nilai rating bobot ternormalisasi dengan bobot kepentingan. Nilai dari masing-masing data ternormalisasi (R) kemudian dikalikan dengan bobot (W) untuk mendapatkan matriks keputusan ternormalisasi terbobot (Y). Dengan wj adalah pangkat bernilai positif untuk atribut keuntungan (benefit), dan bernilai negatif untuk atribut biaya (cost). Nilai wj menunjukkan nilai bobot dari kriteria $C$ yang ke-j. Proses perhitungan 


\section{Journal of Software Engineering Ampera}

Vol. 2, No. 1, February 2021 e-ISSN: 2775-2488

https://journal-computing.org/index.php/journal-sea/index

guna menentukan rating bobot ternormalisasi dengan rumus 2, maka didapatkan hasil perhitungan rating kinerja ternormalisasi yang dapat dilihat pada Tabel 5 berikut.

Tabel 5. Rating Bobot Ternormalisasi

\begin{tabular}{|c|c|c|c|c|c|c|c|c|c|c|c|c|}
\hline \multirow{3}{*}{$\begin{array}{l}\text { Alter } \\
\text { natif }\end{array}$} & \multicolumn{12}{|c|}{ Kriteria } \\
\hline & C1 & $\mathrm{C} 2$ & C3 & C4 & $\mathrm{C5}$ & C6 & $\mathrm{C7}$ & $\mathrm{C} 8$ & C9 & C1 & $\mathrm{C} 1$ & C1 \\
\hline & & & & & & & & & & 0 & 1 & 2 \\
\hline \multirow[t]{3}{*}{ A1 } & 3,5 & 2,4 & 2,0 & 1,9 & 2,6 & 2,1 & 2,1 & 2,9 & 2,3 & 1,6 & 1,8 & 2,9 \\
\hline & 00 & 61 & 00 & 69 & 03 & 21 & 21 & 81 & 85 & 97 & 30 & 81 \\
\hline & 7 & 8 & 0 & 5 & 8 & 3 & 3 & 4 & 1 & 1 & 0 & 4 \\
\hline \multirow[t]{3}{*}{$\mathrm{A} 2$} & 0,7 & 1,9 & 2,0 & 2,4 & 3,2 & 2,8 & 2,1 & 2,2 & 1,1 & 1,6 & 1,8 & 1,4 \\
\hline & 00 & 69 & 00 & 61 & 54 & 28 & 21 & 36 & 92 & 97 & 30 & 90 \\
\hline & 1 & 5 & 0 & 8 & 7 & 4 & 3 & 1 & 6 & 1 & 0 & 7 \\
\hline \multirow[t]{3}{*}{ A3 } & 2,8 & 1,9 & 2,0 & 1,4 & 1,9 & 2,8 & 2,8 & 2,9 & 2,3 & 2,2 & 1,8 & 2,2 \\
\hline & 00 & 69 & 00 & 77 & 52 & 28 & 28 & 81 & 85 & 62 & 30 & 36 \\
\hline & 6 & 5 & 0 & 1 & 8 & 4 & 4 & 4 & 1 & 7 & 0 & 1 \\
\hline \multirow[t]{3}{*}{ A4 } & 2,1 & 1,4 & 2,0 & 1,9 & 1,9 & 2,1 & 2,8 & 1,4 & 1,7 & 2,2 & 2,4 & 2,9 \\
\hline & 00 & 77 & 00 & 69 & 52 & 21 & 28 & 90 & 88 & 62 & 40 & 81 \\
\hline & 4 & 1 & 0 & 5 & 8 & 3 & 4 & 7 & 9 & 7 & 0 & 4 \\
\hline
\end{tabular}

Implementasi halaman Rating Bobot Ternormalisasi (yij) dapat dilihat pada Gambar 5 berikut :

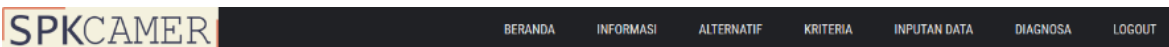

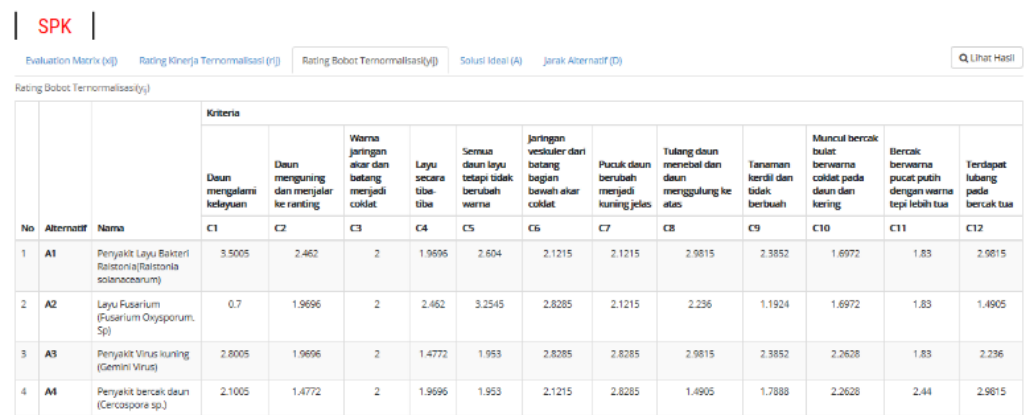

Gambar 5. Halaman Rating Bobot Ternormalisasi (yij) 


\section{Journal of Software Engineering Ampera}

Vol. 2, No. 1, February 2021 e-ISSN: 2775-2488

https://journal-computing.org/index.php/journal-sea/index

\subsubsection{Menentukan Solusi Ideal Positif dan Solusi Ideal Negatif}

Solusi ideal positif A+ dan solusi ideal negatif A- dapat ditentukan berdasarkan ranking bobot ternormalisasi (yij). Nilai Max nilai tertinggi dari setiap kriteria pada matriks ternormalisasi terbobot, sedangkan nilai min adalah nilai terendah dari setiap kriteria pada matriks terbobot. Perhitungan solusi ideal positif dan solusi ideal negatif dengan rumus 3 dan rumus 4, maka didapatkan hasil perhitungan solusi ideal positif dan solusi ideal negatif yang dapat dilihat pada Tabel 6 berikut.

Tabel 6. Solusi Ideal Positif dan Solusi Ideal Negatif

\begin{tabular}{lllllllllllll}
\hline $\begin{array}{l}\text { Sol } \\
\text { usi }\end{array}$ & C1 & C2 & C3 & C4 & C5 & C6 & C7 & C8 & C9 & C10 & C11 & C12 \\
\hline Posi & 0,7 & 1, & 2,0 & 1,4 & 1,9 & 2,1 & 2,1 & 1,4 & 1,1 & 1,6 & 1,8 & 1,4 \\
tif & 00 & 47 & 00 & 771 & 528 & 213 & 213 & 907 & 926 & 971 & 300 & 907 \\
& 1 & 71 & 0 & & & & & & & & & \\
Neg & 3,5 & 2, & 2,0 & 2,4 & 3,2 & 2,8 & 2,8 & 2,9 & 2,3 & 2,2 & 2,4 & 2,9 \\
atif & 00 & 46 & 00 & 618 & 547 & 284 & 284 & 814 & 851 & 627 & 400 & 814 \\
& 7 & 18 & 0 & & & & & & & & &
\end{tabular}

Implementasi halaman Solusi Ideal (A) dapat dilihat pada Gambar 6 berikut :

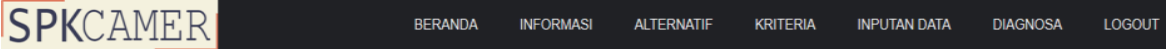

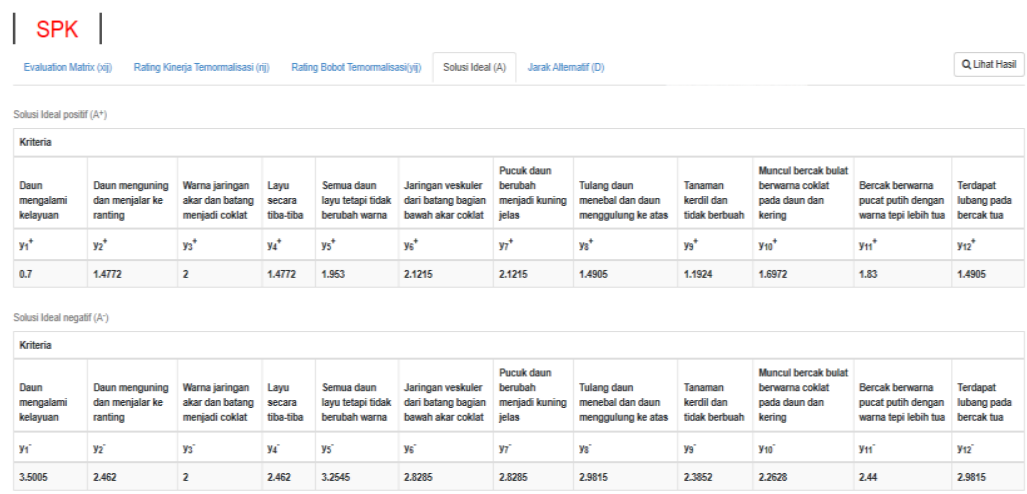

Gambar 6. Halaman Solusi Ideal (A) 


\section{Journal of Software Engineering Ampera}

Vol. 2, No. 1, February 2021 e-ISSN: 2775-2488

https://journal-computing.org/index.php/journal-sea/index

\subsubsection{Menentukan Jarak Solusi Ideal Positif dan Jarak Solusi Ideal Negatif}

Perhitungan jarak alternatif (D), dalam halamam ini ditampilkan nilai Matriks Jarak Solusi Ideal Positif $\left(D^{+}\right)$dan Jarak Solusi Ideal Negatif $\left(D^{-}\right)$. Perhitungan Jarak antara Alternatif $A_{i}$ dengan Solusi Ideal Positif $\left(D^{+}\right)$dengan rumus 5 , maka didapatkan hasil perhitungan jarak solusi ideal positif dan jarak solusi ideal negatif yang dapat dilihat pada Tabel 7 berikut.

Tabel 7. Jarak Solusi Ideal Positif dan Jarak Solusi Ideal Negatif

\begin{tabular}{lllll}
\hline Jarak Solusi & A1 & A2 & A3 & A4 \\
\hline Positif & 3,9174 & 1,9906 & 3,1897 & 2,4440 \\
Negatif & 1,5357 & 3,6712 & 2,0000 & 2,4618
\end{tabular}

Implementasi halaman Jarak Alternatif (D) dapat dilihat pada Gambar 7 berikut:

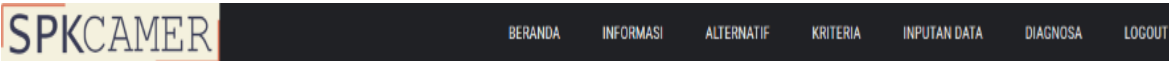

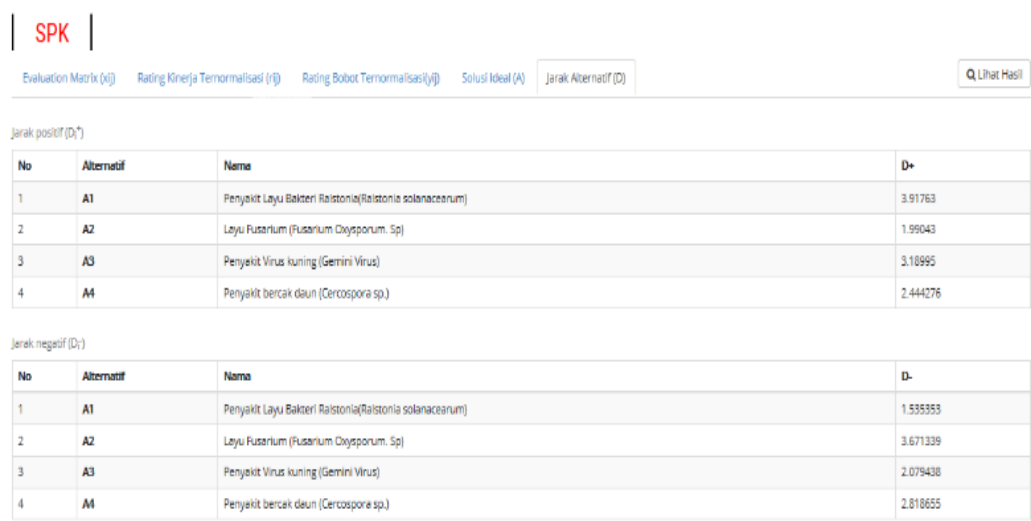

Gambar 7. Halaman Jarak Alternatif (D)

\subsubsection{Menentukan Nilai Preferensi}

Perhitungan nilai preferensi untuk setiap alternatif $\left(\mathrm{V}_{\mathrm{i}}\right)$ atau kedekatan setiap alternatif dengan rumus 7, maka didapatkan hasil perhitungan nilai preferensi yang dapat dilihat pada Tabel 8 berikut. 


\section{Journal of Software Engineering Ampera}

Vol. 2, No. 1, February 2021 e-ISSN: 2775-2488

https://journal-computing.org/index.php/journal-sea/index

Tabel 8. Nilai Preferensi

\begin{tabular}{ccc}
\hline Alternatif & Total & Ranking \\
\hline A1 & 0,2186 & 4 \\
A2 & 0,6484 & 1 \\
A3 & 0,3947 & 3 \\
A4 & 0,5356 & 2
\end{tabular}

Implementasi halaman Lihat Hasil dapat dilihat pada Gambar 8 berikut:

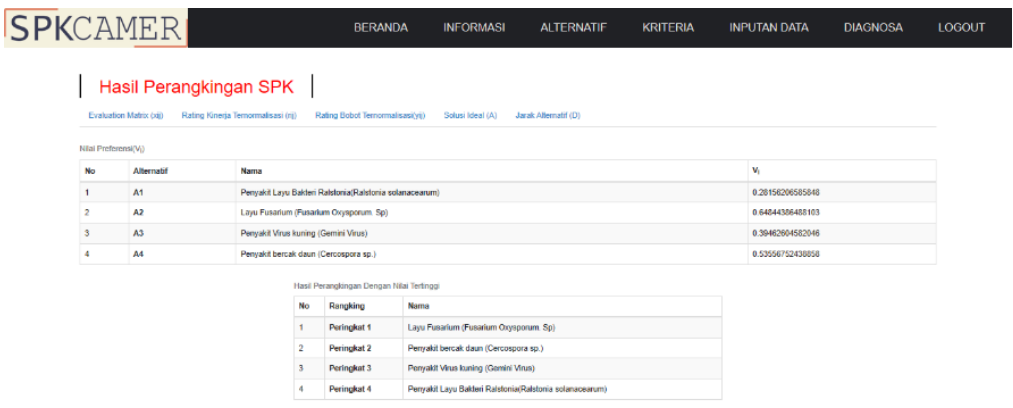

Gambar 8. Halaman Lihat Hasil

\section{KESIMPULAN}

Berdasarkan hasil uraian dan pembahasan laporan tugas akhir ini, kami telah berhasil merancang dan membangun sistem pendukung keputusan diagnosa penyakit tanaman cabai merah menggunakan metode TOPSIS berbasis web di Desa Kerik dengan kesimpulan antara lain :

1. Sistem Pendukung Keputusan Diagnosa Penyakit Tanaman Cabai Merah Menggunakan Metode TOPSIS Berbasis Web telah berhasil dibangun. Sistem pendukung keputusan ini telah berhasil diuji dengan hasil prosentase keberhasilan sebesar 100\% maka dinyatakan layak untuk dapat digunakan. Sehingga sistem pendukung keputusan ini diharapkan mampu untuk membantu para petani di Desa Kerik dalam mendiagnosa penyakit tanaman cabai merah yang mereka budidayakan.

2. Berdasarkan hasil perhitungan yang dilakukan secara manual maupun perhitungan didalam sistem dengan menggunakan metode TOPSIS mendapatkan nilai perhitungan yang sama, maka berhasil mendapatkan akurasi hasil perhitungan kecocokan dengan prosentase sebesar $100 \%$. 


\section{Journal of Software Engineering Ampera}

Vol. 2, No. 1, February 2021 e-ISSN: 2775-2488

https://journal-computing.org/index.php/journal-sea/index

\section{DAFTAR PUSTAKA}

[1] Anggraeni, E. Y., Oktovianto, O., \& Agustina, W. (2016). Sistem Pendukung Keputusan Dalam Diagnosa Penyakit Anemia Dengan Menggunakan Metode Saw ( Simple Additive Weighting ). Seminar Nasional Teknologi Informasi Dan Multimedia 2016, 31-36.

[2] Brahmantyo, H. V., \& Ariyanto, R. (2016). Sistem Pendukung Keputusan Penentuan Tanaman Obat Sesuai Jenis Penyakit Menggunakan Metode Topsis. Jurnal Informatika Polinema, 2(2), 66.https://doi.org/10.33795/jip.v2i2.58

[3] Feriadi, D. (2012). Aplikasi Sistem Pendukung Keputusan Untuk Simulasi Diagnosa Hama dan Penyakit Pada Tanaman Cabai. STMIK Pringsewu Lampung, 106-113.

[4] Irnaldi, R. (2019). Sistem Pakar Diagnosa Penyakit Tanaman Cabai Menggunakan Metode Forward Chaining Berbasis Android. Jurnal Perencanaan, Sainns, Teknologi Dan Komputer, 2(1), 165-174.

[5] Novianti, N., dan Setiawan, R. (2017). Pengembangan Sistem Informasi Jasa Menjahit Berbasis Web Pada Ganesha Tailor Garut. Jurnal Algoritma, 13(2), 246-253. https://doi.org/10.33364/algoritma/v.13-2.246.

[6] Pardede, A., \& Novriyenni, \&. (2018). Perancangan Sistem Pakar Diagnosa Penyakit Tanaman Kelapa Sawit Dengan Metode Bayes Study Kasus PT.Ukindo Blankahan Estate. https://doi.org/10.31219/osf.io/jg3st

[7] Priyono dan Nuzuliarani. (2020). Sistem Pendukung Keputudan Metode TOPSIS Untuk Diagnosa Penyakit Demam Berdarah. Journal of Chemical Information and Modeling, 53(9), 1689-1699.

[8] Puspito, M. A., Hidayat, N., \& Suprapto. (2018). Sistem Pendukung Keputusan Diagnosa Penyakit Tanaman Jeruk Menggunakan Metode Naive Bayes Classifer. Jurnal Pengembangan Teknologi Informasi Dan IImu Komputer, 2(7), 1-6.

[9] Suyono, S., dan Carnovia, C. (2018). Sistem Pendukung Keputusan Menentukan Penyakit Pada Tanaman Kakao Menggunakan Metode Topsis. Explore: Jurnal Sistem Informasi Dan Telematika, 9(1). https://doi.org/10.36448/jsit.v9i1.1034.

[10] Sri Wanti Ginting, N., \& Sindar RMS, A. (2018). Sistem Pakar Diagnosa Penyakit Kacang Kedelai Menggunakan Metode Certainty Factor. UPI YPTK Jurnal KomTekInfo, 5(1), 36-41. 